\title{
REMOVAL OF URANIUM FROM LIQUID WASTE BY NATURAL NILE MUD
}

\author{
M. Zaky1, A.E.M. Hussein ${ }^{2 *}$, M.M. Fawzy², Kh. Elgendy ${ }^{1}$, Y. Bakr ${ }^{2}$ \\ ${ }^{1}$ Zagazig University, Faculty of Science, Department of Chemistry. \\ ${ }^{2}$ Nuclear Materials Authority, Cairo, Egypt \\ *E-mail of corresponding author: ah_mady@yahoo.com \\ Phone No.: +201011529962 Fax No.: +202 27585832 \\ Address: Nuclear Materials Authority, Box 530, El-Maadi, Cairo, Egypt
}

\begin{abstract}
This effort deals with uranium removal from liquid waste using Natural Nile Mud (NNM). Accordingly, cost effective and simple approach to remove uranium from liquid waste by NNM was reported. The effects of shaking time, $\mathrm{pH}$, the initial uranium concentration, adsorbent temperature, adsorbent amount (dose) and effect of foreign ion (iron) on the adsorption of uranium ions from liquid waste were examined. According to the results, the optimum conditions for maximum adsorption efficiency of the NNM for uranium from the solution were obtained fitted with the Langmuir and the maximum adsorption capacity was about $61 \mathrm{mg} / \mathrm{g}$ NNM.
\end{abstract}

Key word: Uranium adsorption, Natural Nile Mud, Adsorption isotherm.

\section{Introduction}

Presence of uranium naturally in the soil, rocks and sea water is giving an attention because of its radioactive properties and its toxicity for human and other living organisms. Uranium poses a serious threat to human health and the environment because it can enter the food chain and ultimately be consumed by humans, thus resulting in serious Lung, Kidney, Liver damages, Cancer, Leukemia, genetic aberrations, and even death. On the other hand, separation process and benefit in the nuclear field. Naturally, uranium occurs in most natural waters at very low concentrations, but in case of chemical processing and mining, milling, processing, enriching, all of these processes causes increasing of uranium concentration up to $50 \mathrm{mg} / \mathrm{ml}$. Thus removal of uranium from wastes should be emphasized because of the double significance of latent environmental hazards and as a nuclear energy source. 
Uranium toxicity and radioactivity is the reason for purification and elimination from the surrounding environment. The lowest standard radioactive waste is fixed to $5 \mathrm{mg} / \mathrm{L}[1,2]$. In this respect, many adsorbents have been developed and proposed to deal with these wastes, such as Activated Carbon[3], Bentonite[4], Chitosan[5], Peat[6], Agricultural byproducts [7], and tea waste [8] and Coffee wastes [9], wood powder and wheat straw [10], Carbon nanotubes [11], activated carbon prepared from olive stones [12]. Between all the adsorbents natural clays are economically, viable and environ-mentally acceptable materials for uranium adsorption. The structural characteristic of the clay that is aluminum silicates having unique ion exchange properties, support uranium adsorption mechanism that is mainly pure ion exchange reactions also presence of a negative charges on the clay surface which can attract positively charged metal ions [13]. There are acavities occupied by $\mathrm{Al}^{3+}$ and $\mathrm{Si}^{4+}$ cations which can be substituted in the basic structure [5].

The adsorption efficiency of the clay for uranium is function of several factors as solution $\mathrm{pH}$, shaking time, temperature, initial concentration and solid/liquid ratio. The objective of this work is to explore the possibility of using the natural Nile mud (NNM) for uranium (VI) adsorption from the radioactive waste liquor as a low cost adsorbent. In this regard batch experiments were carried out to choose the preferred adsorption conditions. Uranium (VI) adsorption efficiency was taken as a function of the subsequent parameters of contact time, solution $\mathrm{pH}$, initial uranium concentration, adsorption temperature, adsorbent amount and effect of forging ion. The adsorption isotherms were analyzed to attain the Langmuir and Freundlich constants. The obtained results gave a better empathetic of the NNM adsorption of uranium phenomenon.

\section{Materials and analytical procedure}

\subsection{Preparation of the uranium standard solution}

A uranium stock standard solution assaying $1000 \mathrm{mg} / \mathrm{L}$ was prepared by dissolving $0.1782 \mathrm{~g}$ of uranyl acetate $\left[\mathrm{UO}_{2}\left(\mathrm{CH}_{3} \mathrm{COO}\right)_{2} 2 \mathrm{H}_{2} \mathrm{O}\right]$ of $\mathrm{BDH}$ Chemicals Ltd. Poole, England in $1000 \mathrm{ml}$ distilled water. Uranium was analyzed in the different working aqueous phases using Arsenazo III spectrophotometric method. The formed uranium Arsenazo III complex was measured at $650 \mathrm{~nm}$ against standard solutions using a Perkin-Elmer, USA UV/VIS spectrophotometer. On the other hand, $\mathrm{Ca}^{2+}$ and $\mathrm{Fe}^{3+}$ were determined spectrophotometrically using the methods described by Marczenko [14]. 


\subsection{Characterization for the working liquid and sample}

The liquid waste sample used in this study was provided by the Nuclear Material Authority, Uranium purification unit, Egypt. Its average chemical composition is shown in Table (1).

Table (1): Chemical composition of the working liquid waste sample

\begin{tabular}{cl}
\hline Constituent & g/L \\
\hline $\mathrm{Fe}_{2} \mathrm{O}_{3}$ & 2.3 \\
$\mathrm{CaO}$ & 7.0 \\
$\mathrm{U}$ & 0.3 \\
\hline
\end{tabular}

The working NNM sample was obtained from agriculture land of Zagazig city district, Egypt. The raw sample was weight, dried at $70{ }^{\circ} \mathrm{C}$, refined, and sieved to remove impurities (large particles, and then ground to powder to pass through $250 \mu \mathrm{m}$ sieves. The chemical composition of the working sample (Surface Area=33.084 m²/g) were listed in Table (2).

Table (2): Chemical composition of the working NNM

\begin{tabular}{cccc}
\hline Constituent & Wt., \% & Constituent & Wt., \% \\
\hline $\mathrm{SiO}_{2}$ & 53.2 & $\mathrm{MnO}$ & 0.36 \\
$\mathrm{Al}_{2} \mathrm{O}_{3}$ & 11.8 & $\mathrm{TiO}_{2}$ & 2.66 \\
$\mathrm{Fe}_{2} \mathrm{O}_{3}$ & 20.1 & $\mathrm{P}_{2} \mathrm{O}_{5}$ & 0.82 \\
$\mathrm{CaO}$ & 8.60 & Loss of ignition & 0.61 \\
$\mathrm{~K}_{2} \mathrm{O}$ & 1.85 & & \\
\hline
\end{tabular}

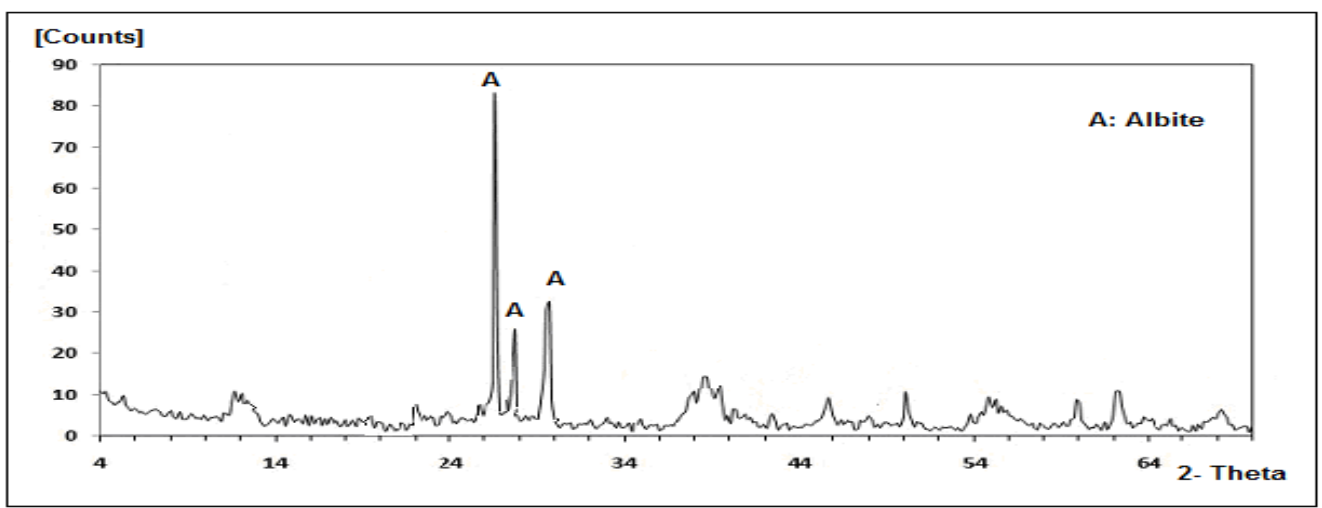

Fig. (1): XR-D Pattern for Natural Nile Mud sample [Albite; $\left.\mathrm{Na}, \mathrm{Ca}(\mathrm{Si}, \mathrm{Al})_{3} \mathrm{O}_{8}\right]$.

\subsection{Preparation of the working sample}

The working sample was prepared as it was described by Breen and Watson [15]. The sample was agitating for 1 hour with [5M] of $\mathrm{HCl}, \mathrm{HNO}_{3}$ and $\mathrm{H}_{2} \mathrm{SO}_{4}$. In addition to calcination at $600^{\circ} \mathrm{C}$ for 2 hours sample were followed 
by agitating for 1 hour with the same acids concentrations [16]. Afterwards, the acid treated, and calcined samples were washed with water and dried at room temperature (in the open air). The treated Nile Mud (TNM) samples were contacted with prior prepared uranium stander solution portions (20 $\mathrm{ml}$ ) of $100 \mathrm{ppm}$ for 1 hour.

The adsorbed amounts of uranium were calculated by the difference between its equilibrium and initial concentrations. From the results tabulated in Table (3), about $89 \%$ of uranium adsorption efficiency was achieved by the Natural Nile Mud. Consequently, the authors have been decided to use the Natural Nile Mud (NNM) without treatment in further experiments.

Table (3): Treatment methods of the working sample and its adsorption efficiencies.

\begin{tabular}{lc}
\hline \multicolumn{1}{c}{ Treatment methods } & Adsorption efficiency, \% \\
\hline 1. Natural form & 89.8 \\
2. Calcination at $600^{\circ} \mathrm{C}$ for two hours & 84.0 \\
3. Acid treated with $\mathrm{HCl}$ & 59.9 \\
4. Acid treated with $\mathrm{HNO} 3$ & 64.0 \\
5. Acid treated with $\mathrm{H} 2 \mathrm{SO} 4$ & 52.0 \\
6. Calcination then $\mathrm{HCl}$ treatment & 85.1 \\
7. Calcination then $\mathrm{HNO} 3$ treatment & 67.0 \\
8. Calcination then $\mathrm{H} 2 \mathrm{SO} 4$ treatment & 55.0 \\
\hline
\end{tabular}

\subsection{Equilibrium Studies}

For studying the relevant factors affecting the adsorptions operation, series of experiments were performed using the previous stock uranium synthetic solution. These factors involved contact time, $\mathrm{pH}$, initial uranium concentration, effect of adsorbent amount (dose) and effect of foreign ion (iron). From the achieved results, Langmuir and Freundlich isotherms were determined. The adsorption experiments were performed by shaking $0.05 \mathrm{~g}$ sample portions of the NNM sample with $20 \mathrm{ml}$ of the uranium synthetic solution (of $100 \mathrm{mg} / \mathrm{L}$ initial uranium concentration) using a magnetic stirrer. The adsorbed amounts of uranium were calculated by the difference between its equilibrium and initial concentrations.

\subsection{Equilibration calculation}

All uranium speciation in this study were performed with Hydra-MEDUSA, a chemical equilibrium calculation program [17]. 


\section{Results and discussion}

\subsection{Results of uranium adsorption}

\subsubsection{Effect of contact time}

To investigate the effect of contact time for uranium adsorption on NNM a sires of experiments were conducted by contacting a fixed weight $(0.05 \mathrm{~g})$ of NNM with a uranium solution $(20 \mathrm{ml})$ having a concentration of $100 \mathrm{mg} / \mathrm{L}$ at room temperature $\left(25^{\circ} \mathrm{C}\right)$ and $\mathrm{pH} 3$. The studied time ranged from 5 up to 180 minutes. From the obtained results which plotted in Fig. (2), the uranium adsorption efficiency attained about $40 \%$ at the first for 5 minutes contact time. By increasing the contact time from 5 to 30 minutes significant uranium adsorption efficiencies (56\% to $86 \%$ ) were observed. Beyond 30 minutes contact time, a clear flat terrain was observed. For that reason, the 30 minutes contact time could be selected as the applicable time.

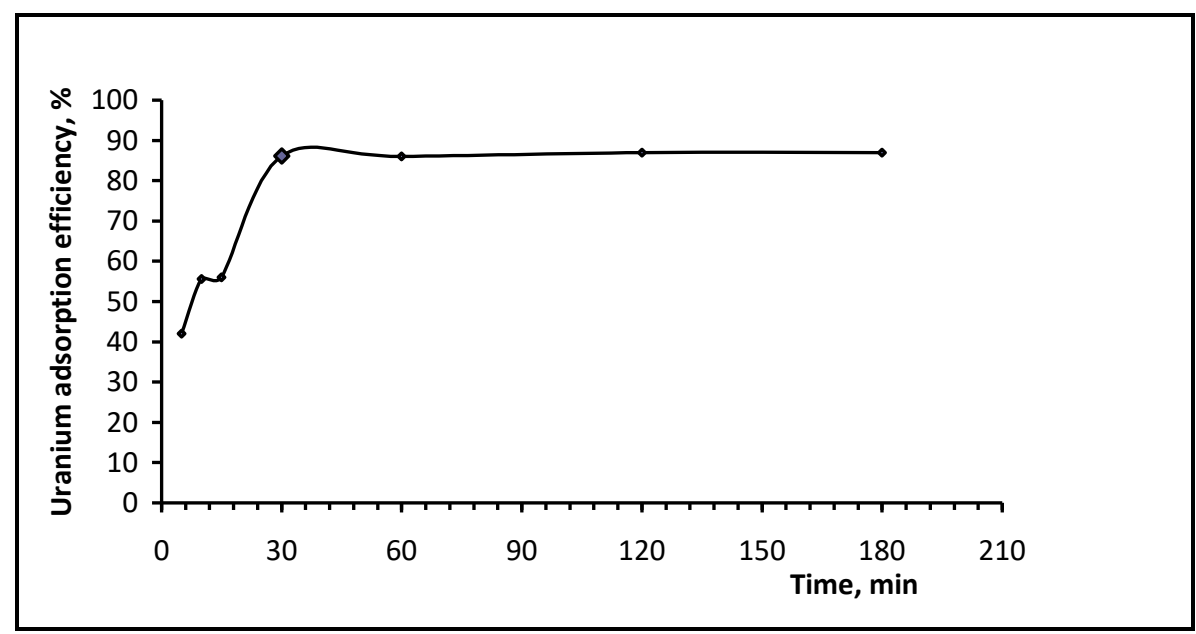

Fig. (2): Effect of contact time upon the uranium adsorption efficiency on the NNM sample.

\subsubsection{Effect of $\mathbf{p H}$}

The influence of solution $\mathrm{pH}$ on the adsorption of uranium on NNM was studied by contacting a fixed weight of the adsorbent NNM $(0.05 \mathrm{~g})$ with sample $(20 \mathrm{ml})$ of uranium standard solution of $100 \mathrm{mg} / \mathrm{L}$ at $25^{\circ} \mathrm{C}$ for 30 minutes. The investigated $\mathrm{pH}$ ranged from $\mathrm{pH} 1$ to 7 . From the obtained data which are shown in Fig. (3), uranium adsorption efficiency increases gradually with increasing $\mathrm{pH}$ values till $\mathrm{pH} 3$ (the peak of the Figure) of 93\%. Beyond $\mathrm{pH} 3$, uranium adsorption efficiency deceases to about $70 \%$ at the last experiment of $\mathrm{pH}$ 6. Then the adsorption efficiency is sharply decreases to about $4 \%$ at $\mathrm{pH}$ of 7 . Thus, it can conclude recommend the use of solution $\mathrm{pH}$ having $\mathrm{pH}$ value of 3 . 


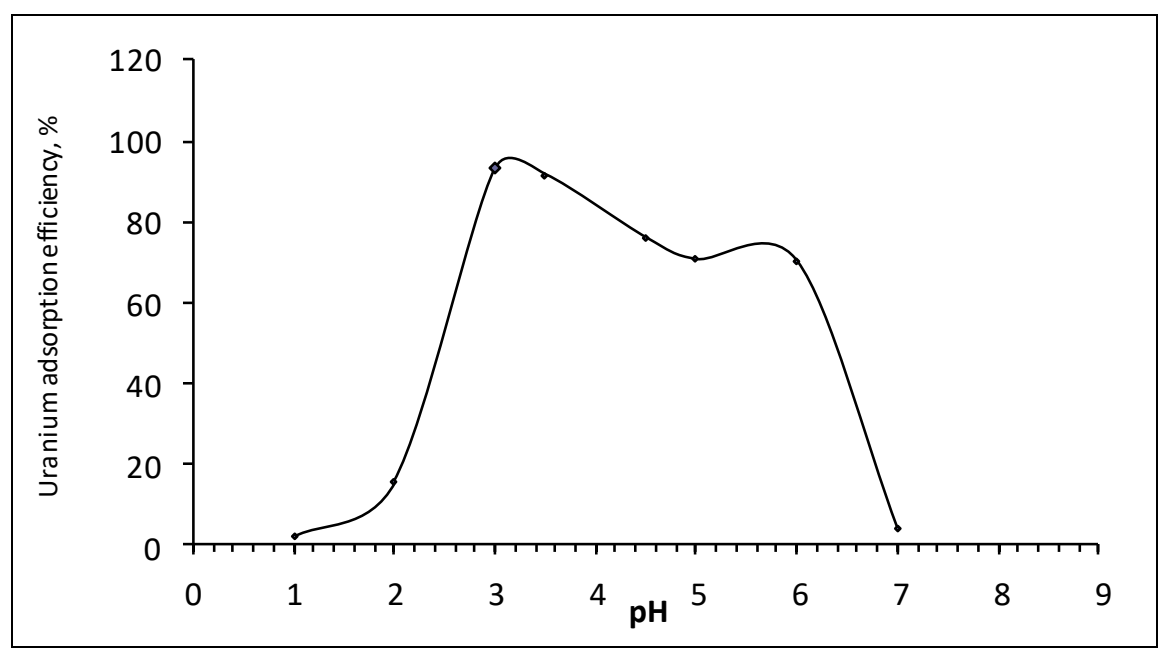

Fig. (3): Effect of solution pH on uranium adsorption efficiency onto NNM.

It is important to mention that uranium adsorption is strongly depending on the solution $\mathrm{pH}$. At low $\mathrm{pH} \leq 3$, the number of $\mathrm{H}_{3} \mathrm{O}^{+}$ions exceeds that of the $\mathrm{UO}_{2}{ }^{2+}$ several times and the surface is most likely covered with $\mathrm{H}_{3} \mathrm{O}^{+}$ions, reducing the number of binding sites for the adsorption of $\mathrm{UO}_{2}{ }^{2+}$. When $\mathrm{pH}$ increases $\geq 3$, more $\mathrm{H}_{3} \mathrm{O}^{+}$ions leave the clay mineral surface making the sites available to the cation exchange with the $\mathrm{UO}_{2}{ }^{2+}$ ions and hydrolysis precipitation starts due to the formation of complexes in aqueous solution, i.e. $\mathrm{UO}_{2}(\mathrm{OH})^{+}, \quad\left(\mathrm{UO}_{2}\right)_{2}(\mathrm{OH})_{2}{ }^{2+}, \quad\left(\mathrm{UO}_{2}\right)_{3}(\mathrm{OH})_{5}^{3+}, \quad\left(\mathrm{UO}_{2}\right)(\mathrm{OH})_{2}$, which increase uranium (VI) adsorption [18]. Aqueous speciation distribution of uranium was calculated and represented in Fig. (4) [19].

The results showed that the complexes of $\mathrm{UO}_{2}\left(\mathrm{NO}_{3}\right)^{+}$and $\mathrm{UO}_{2}{ }^{2+}$ were the predominant species at the $\mathrm{pH}$ range from $(0-3)$ with mean total percent of $15 \%$ and $85 \%$ respectively. U-hydroxide complexes start to dominate the aqueous phase at $\mathrm{pH}$ near 3 of $\left(\mathrm{UO}_{2}\right)_{2}(\mathrm{OH})_{2}{ }^{2+}$ and $\left(\mathrm{UO}_{2}\right)_{2} \mathrm{OH}^{3+}$. At $\mathrm{pH} 4$, the $\mathrm{UO}_{2}(\mathrm{OH})_{2} \cdot \mathrm{H}_{2} \mathrm{O}_{(\mathrm{C})}$ became the major species with about $100 \%$ of total concentration at $\mathrm{pH}$ range from 4.5 to 12 while at $\mathrm{pH} 12, \mathrm{UO}_{2}(\mathrm{OH})_{4}{ }^{2-}$ became the predominant species within a total percent $100 \%$ of the total concentration. 


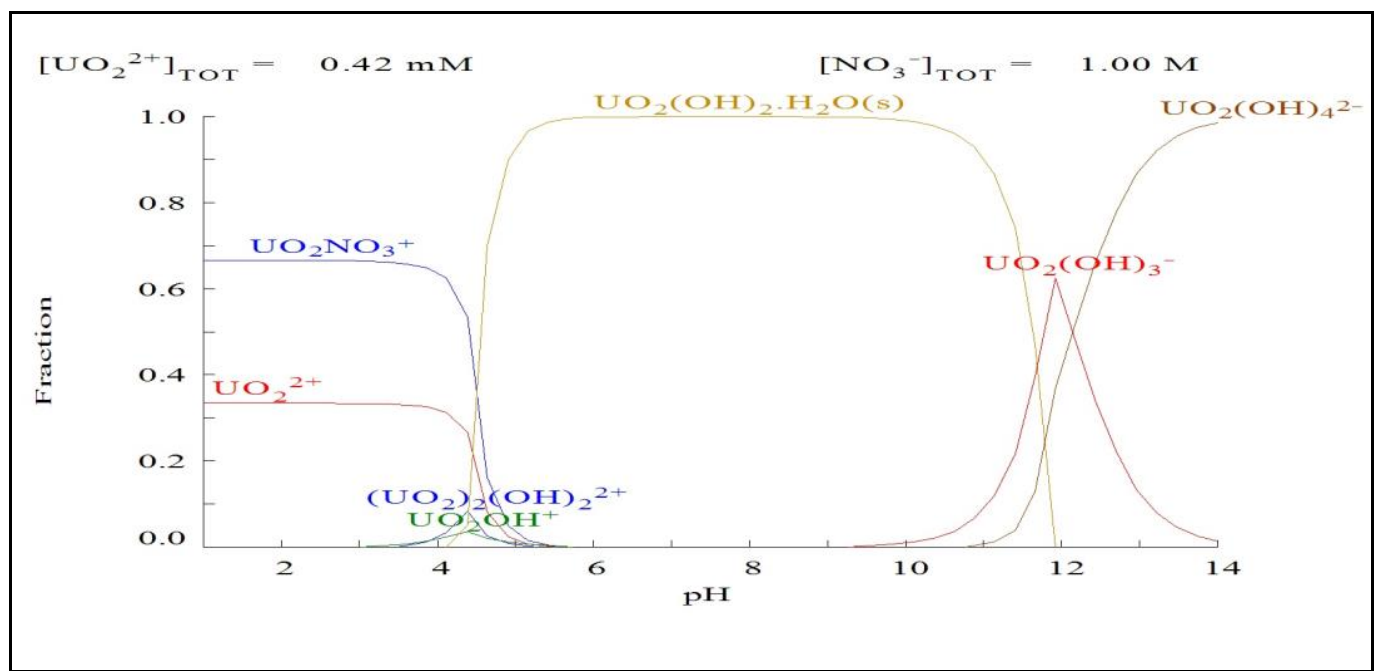

Fig. (4): Predicted aqueous speciation of uranium $(100 \mathrm{mg} / \mathrm{L})$ as a function of $\mathrm{pH}$ in $[1.0 \mathrm{M}] \mathrm{HNO}_{3}$

\subsubsection{Effect of initial uranium concentration}

To investigate the effect of initial uranium concentration upon the adsorption efficiency onto NNM, a series of experiments was performed by contacting a fixed weight $(0.05 \mathrm{~g})$ for $30 \mathrm{~min}$. at room temperature $\left(\sim 25^{\circ} \mathrm{C}\right)$ and $\mathrm{pH} 3$. The studied initial uranium concentrations ranged from 50 up to $600 \mathrm{mg} / \mathrm{L}$. The obtained results were plotted in Fig. (5), it is noticeable that uranium adsorption efficiency decreases with increasing its initial concentration and the experimental maximum capacity is about $60 \mathrm{mg} / \mathrm{g}$ NNM.

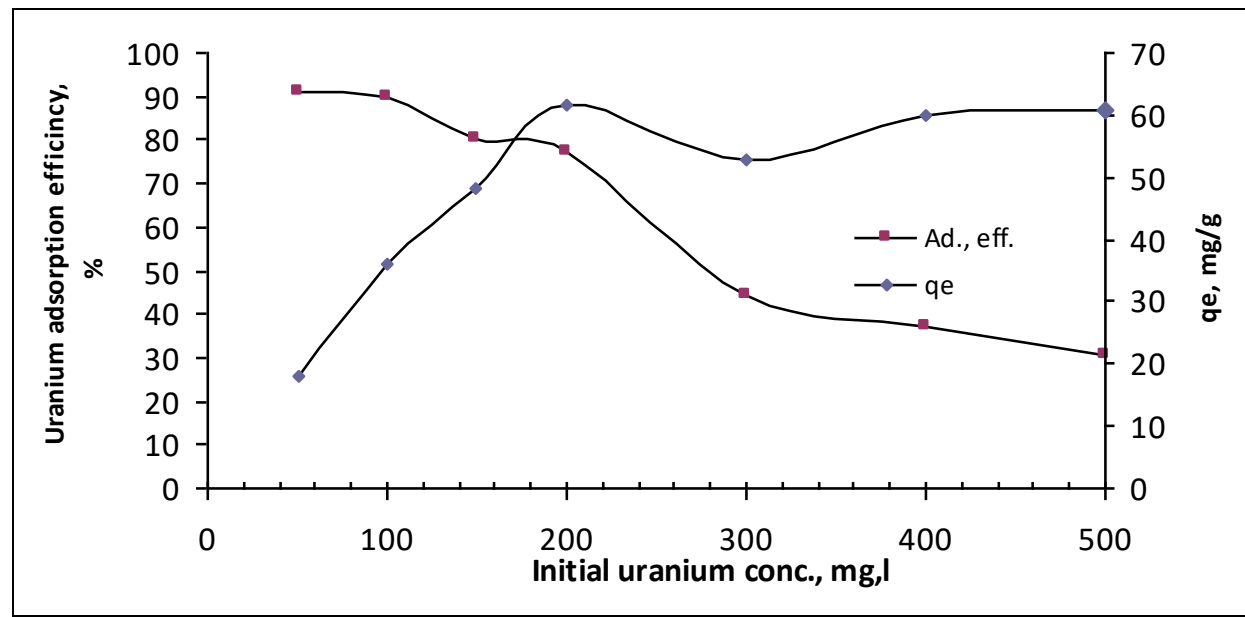

Fig. (5): Effect of initial uranium concentrations on uranium adsorption efficiency onto the NNM. 


\subsubsection{Effect of adsorption temperature}

To investigate the effect of temperature on the uranium adsorption onto the NNM, a series of adsorption experiments were performed by contacting fixed NNM portions $(0.05 \mathrm{~g})$ with synthesized uranium stander solution. The temperatures were ranging from $25^{\circ} \mathrm{C}$ up to $70^{\circ} \mathrm{C}$. The other experimental parameters were kept constant of initial uranium concentration of $100 \mathrm{mg} / \mathrm{L}$ a constant $\mathrm{pH}$ of 3 and a contact time of $30 \mathrm{~min}$. From the obtained results plotted in Fig. (8), it was obvious that uranium adsorption efficiency decreased with the increase of temperature. Accordingly, we decided to apply $\left(25^{\circ} \mathrm{C}\right)$ as optimum temperature.

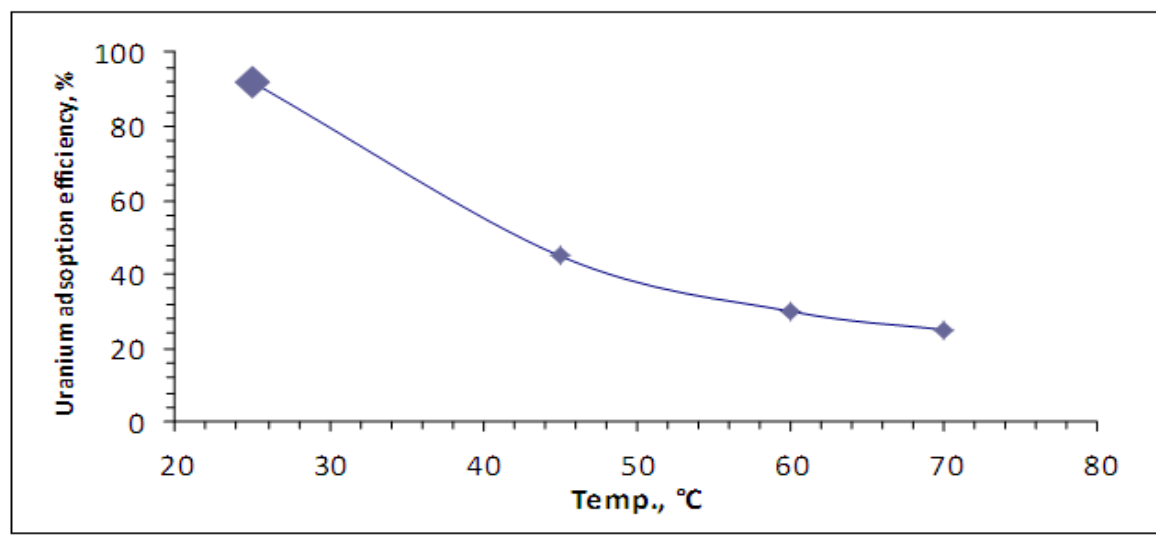

Fig. (8): Effect of temperature on uranium adsorption efficiency onto NNM.

\subsubsection{Effect of adsorbent amount}

As it is known, the quantity of the NNM used in uranium adsorption process is very important for economic point of view. The effect of adsorbent content on the uptake of uranium was verified in Fig. (9). A series of adsorption experiments was performed using different adsorbent doses ranging from 1.25 up to $15 \mathrm{~g} \mathrm{NNM} / \mathrm{L}$. The later experiments were performed by contacting fixed NNM amount of $0.05 \mathrm{~g}$ under constant initial uranium concentration of 100 $\mathrm{mg} / \mathrm{L}$ at room temperature $\left(\approx 25^{\circ} \mathrm{C}\right)$ for $30 \mathrm{~min}$. shaking time and $\mathrm{pH} 3$. From the attained results the adsorption efficiency is slightly increases by increasing the NNM amount from 1.25 to $2.5 \mathrm{~g} \mathrm{NNM} / 1$ the corresponding adsorption efficiency was about 83 and $90 \%$ respectively. By increasing adsorbent amount further $2.5 \mathrm{~g} \mathrm{NNM/L}$ the adsorption efficiency starting to decrease significantly. This is due to the increases of the active sites on the adsorbent and fixing of the presented amount of uranium in the solution. Therefore, the $2.5 \mathrm{~g} \mathrm{NNM} / \mathrm{L}$ adsorbent dose was selected as the optimum dose. 


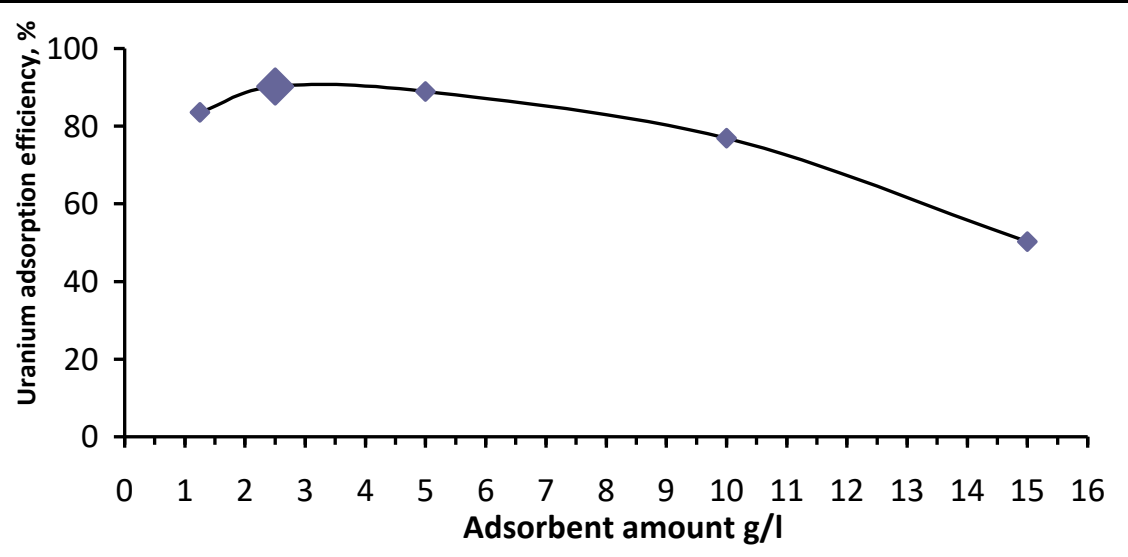

Fig. (9): Effect of adsorbent amount on uranium adsorption on to NNM

\subsubsection{Effect of interfering element (Iron)}

The impact of the existing amounts of iron on the adsorption efficiency of uranium on to the prepared NNM was investigated by the contact fixed sample $(0.05 \mathrm{~g})$ with uranium solution $(100 \mathrm{mg} / \mathrm{L})$ with different additions of $\mathrm{Fe}^{3+}$ ranging 50-300 mg/L.

The other factors were fixed at 30 minutes contact time, $\mathrm{pH}$ of 3.0 and at room temperature. The results were plotted in Fig. (10). From the figure it is observed that the adsorption of uranium is slightly decreases from about 91 to $87 \%$ with an increasing of the iron added amounts this from zero to $150 \mathrm{mg} / \mathrm{L}$ respectively. Beyond the third experiment the efficiency was decreased significantly down to $16 \%$ at the last experiment. This phenomenon could be explained by the adsorption competition between iron and uranium. Therefore, we can conclude that the suitable iron concentration not more than $150 \mathrm{mg} / \mathrm{L}$.

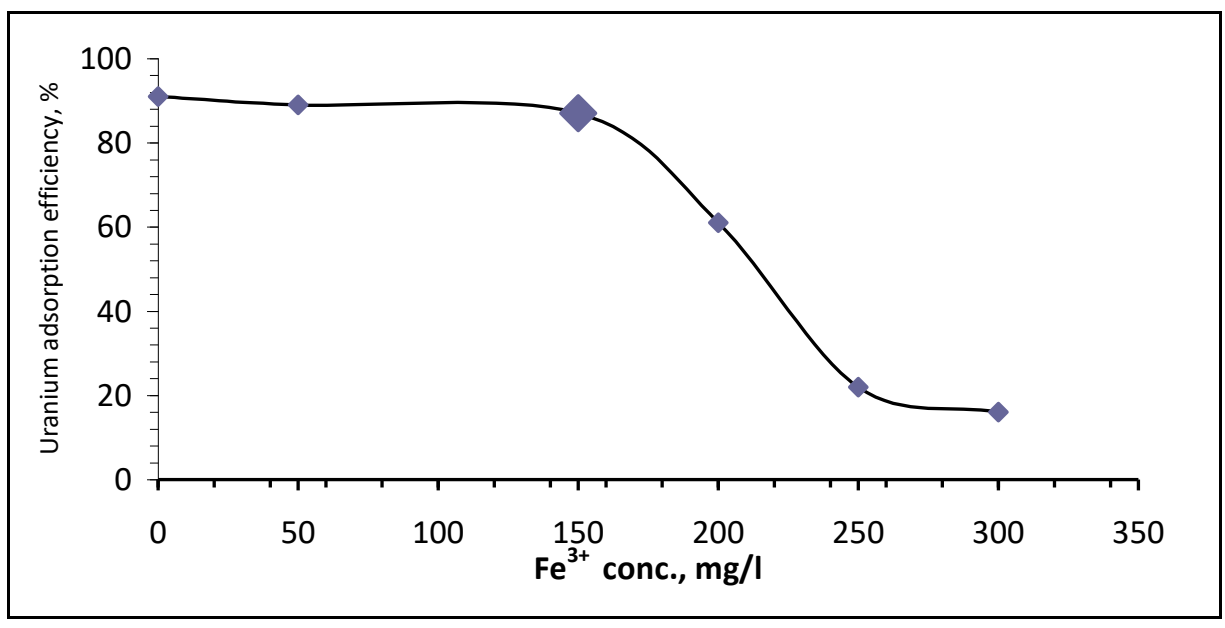

Fig. (10): Effect of added iron amounts upon uranium adsorption efficiency onto NNM. 


\subsection{Adsorption isotherm}

Several common adsorption isotherm models were considered to fit the obtained isotherm data under the equilibrium adsorption of the NNM. Examples of these models are Langmuir and Freundlich isotherms.

\section{$A$ - Langmuir isotherm}

According to the Langmuir model, adsorption occurs uniformly on the active sites of the sorbent, and once a sorbate occupies a site, no further sorption can take place at this site. Thus, Langmuir model is given by the following equation [20]:

$$
C_{e} / q_{e}=1 / b Q_{o}+C_{e} / Q_{o}
$$

Where: $Q_{o}$ and $b$, Langmuir constants, are the saturated monolayer sorption capacity and the sorption equilibrium constant, respectively.

A plot of $C_{e} / q_{e}$ versus $C_{e}$ would result in a straight line with a slope of $\left(1 / \mathrm{Q}_{0}\right)$ and intercept of $1 / b Q_{o}$ as seen in Fig. (6). Langmuir parameters given in Table (17) can be used to predict the affinity between the sorbate and sorbent using the dimensionless separation factor $\mathrm{R}_{\mathrm{L}}[\mathbf{2 1}, \mathbf{2 2}]$

$$
R_{L}=1 /\left(1+b C_{o}\right)
$$

$R_{L}$ value indicate the type of isotherm to be irreversible $\left(R_{L}=0\right)$, favorable $\left(0<R_{L}<1\right)$, linear $\left(R_{L}=1\right)$ and unfavorable $\left(R_{L}>1\right)$. The values of $R_{L}$ for adsorption of uranium (VI) onto NNM are shown in Fig. (7), which indicate that adsorption of uranium (VI) is more favorable at higher initial uranium (VI) concentrations than at lower concentrations.

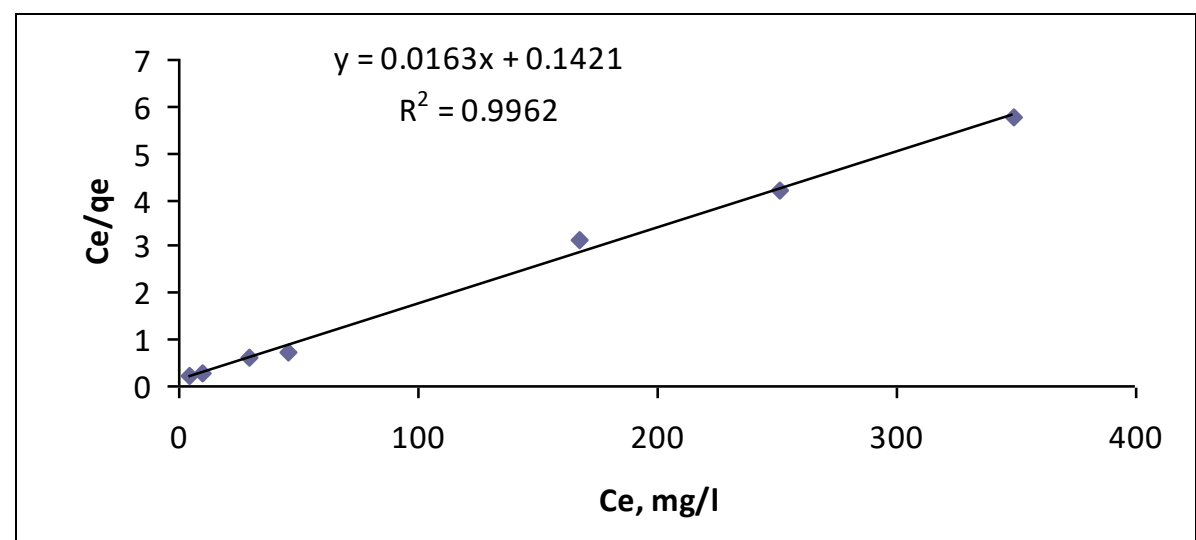

Fig. (6): Langmuir isotherm plots for adsorption of uranium onto NNM. 


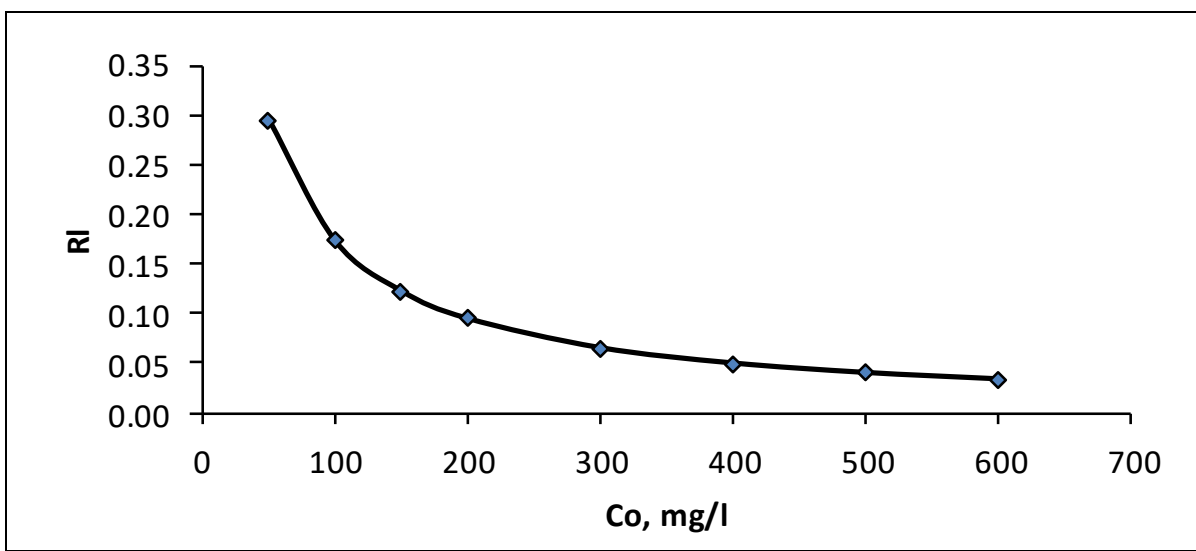

Fig. (7): Separation factor $R_{L}$ of uranium (VI) adsorbed onto NNM.

\section{$B$ - Freundlich Isotherm:}

The Freundlich model stipulates that the ratio of solute adsorbed to the solute concentration is a function of the solution. The empirical model was shown to be consistent with exponential distribution of active centers, characteristic of heterogeneous surfaces.

The amount of solute adsorbed at equilibrium, $\mathrm{q}_{\mathrm{e}}$, is related to the concentration of solute in the solution, $\mathrm{C}_{\mathrm{e}}$, following [21, 22]:

$$
q_{e}=K_{F} C_{e}{ }^{1 / n}
$$

This expression can be linearized to give:

$$
\log q_{e}=\log K_{F}+(1 / n) \log C_{e}
$$

Where $\mathrm{K}_{\mathrm{F}}$ and $\mathrm{n}$ are the Freundlich constants, which represent sorption capacity and sorption intensity, respectively. A plot of $\left(\log q_{e}\right)$ versus $\left(\log C_{e}\right)$ would result in a straight line with a slope of $(1 / n)$ and intercept of $\left(\log K_{F}\right)$ as seen in Fig. (7). Freundlich constants are given in Table (4).

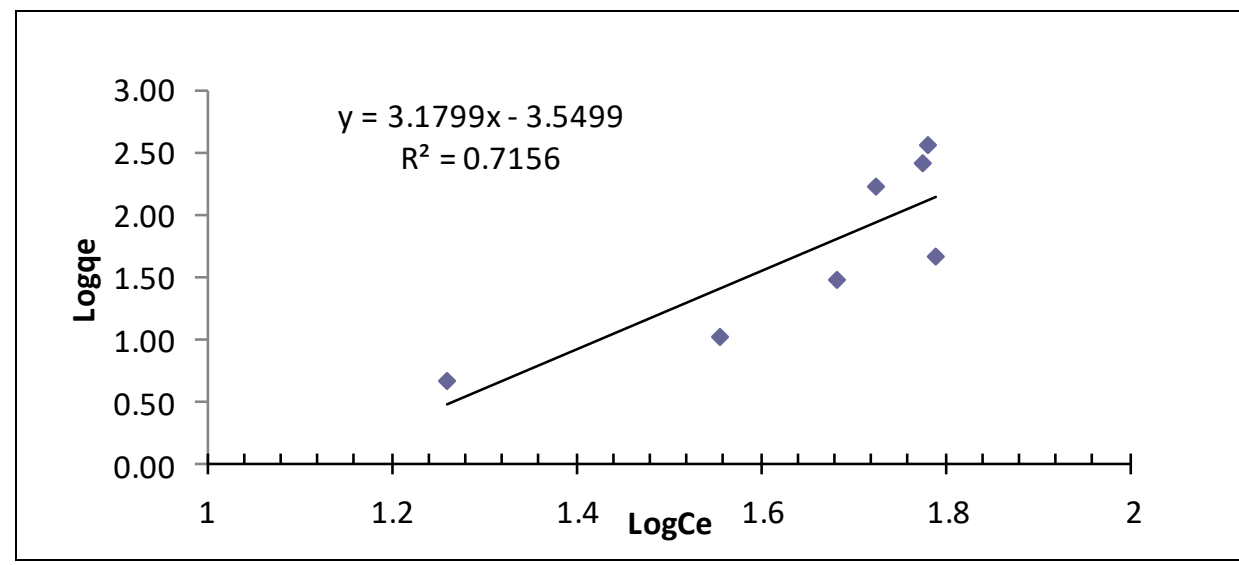

Fig. (7): Freundlich isotherm plots for adsorption of uranium onto NNM. 
Table (4): Langmuir and Freundlich parameters for uranium adsorption on NNM

\begin{tabular}{|c|c|c|c|c|c|c|c|}
\hline \multirow{2}{*}{ Metal } & \multirow{2}{*}{ Adsorbent } & \multicolumn{3}{|c|}{$\begin{array}{c}\text { Langmuir model } \\
\text { parameters }\end{array}$} & \multicolumn{3}{|c|}{$\begin{array}{c}\text { Freundlich model } \\
\text { parameters }\end{array}$} \\
\hline & & $\underset{(m g / g)}{Q^{\circ}}$ & $\begin{array}{c}b \\
(L / m g)\end{array}$ & $R^{2}$ & $1 / n$ & $\begin{array}{c}K_{f} \\
(m g / g)\end{array}$ & $\overline{R^{2}}$ \\
\hline Uranium & $\begin{array}{c}\text { Natural Nile } \\
\text { Mud } \\
\end{array}$ & 61.34 & 0.114 & 0.99 & 0.31 & 0.0002 & 0.71 \\
\hline
\end{tabular}

\section{Choice of the preferred adsorption conditions}

From the attained results of the relevant factors affecting uranium adsorption onto the prepared NNM, careful selection of the preferred values of these results would depend primarily on economic considerations. In the light of the studied factors, it would seem economic to select the following conditions for uranium removal by the prepared NNM as followed in Table (5). By applying the obtained preferred conditions, about $92 \%$ adsorption efficiency was attended.

Table (5): Investigated parameter and optimum conditions affecting uranium adsorption onto NNM.

\begin{tabular}{|l|c|}
\hline Parameters & Optimum conditions \\
\hline $\mathbf{p H}$ & 3 \\
\hline Contact Time & $30 \mathrm{~min}$ \\
\hline Initial uranium Conc. & $100 \mathrm{ppm}$ \\
\hline Treatment conditions & Natural form \\
\hline Adsorbent mass (dose) & $2.5 \mathrm{~g} / \mathrm{L}$ \\
\hline Temperature & $25^{\circ} \mathrm{C}$ \\
\hline Interfering element & Not more than $150 \mathrm{ppm}$ \\
\hline Capacity & $61.34 \mathrm{mg} / \mathrm{g}$ \\
\hline
\end{tabular}

\section{FT-IR}

The results of IR spectroscopy of NNM Fig. (11-a) show the characteristic bands of albite [23]: $\mathrm{OH}^{-}$at 3868, 3698, 3620, 3426, $2388 \mathrm{~cm}^{-1} ; \mathrm{Al}-\mathrm{OH}$ at1633, $1434 \mathrm{~cm}^{-1} ; \mathrm{Si}-\mathrm{O}$ at $1032,778,469 \mathrm{~cm}^{-1}$ and $\mathrm{Si}-\mathrm{O}-\mathrm{Al}(\mathrm{VI})$ at $693 \mathrm{~cm}^{-1}$. Absence of the detectable $\mathrm{OH}^{-}$at $2388, \mathrm{Al}-\mathrm{O}-\mathrm{H}$ band at $1434 \mathrm{~cm}^{-1}$ and the starching occurred in the band at $1030 \mathrm{~cm}^{-1}$ is evident from Fig. (11b) can be related to the complexation between uranium and the NNM surface. 


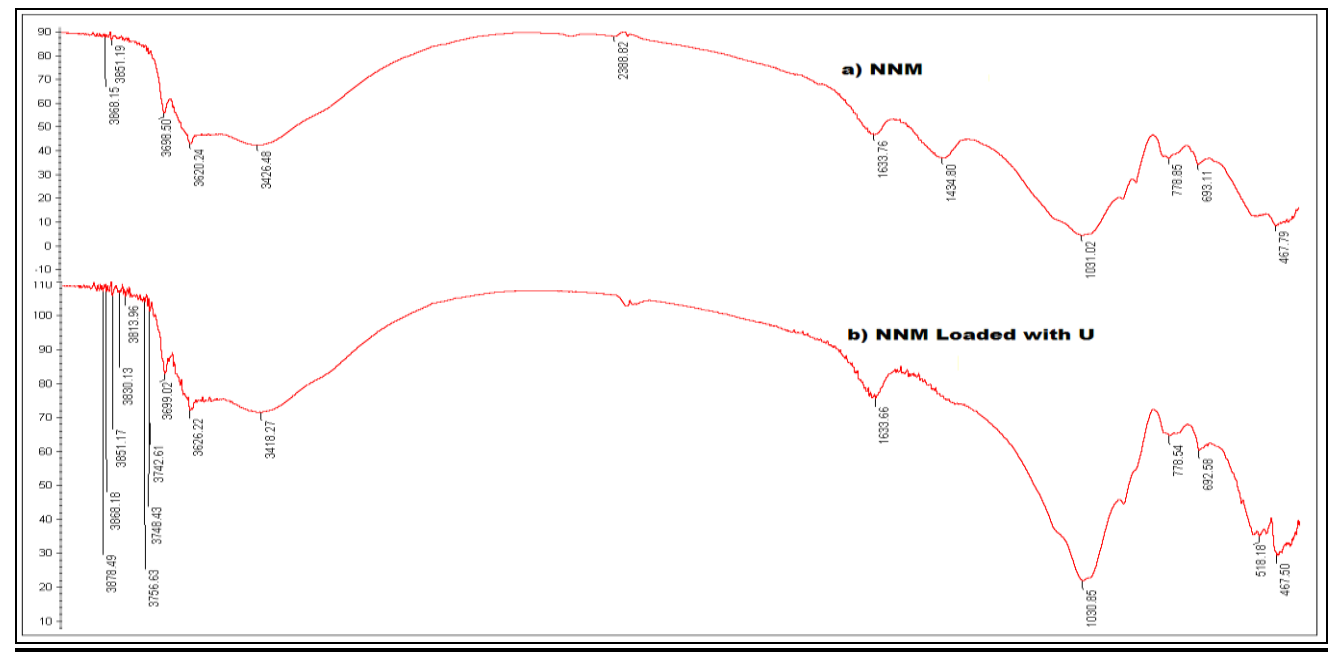

Fig. (11): (a) IR Spectra of NNM, (b) IR spectra NNM loaded with uranium.

\section{SEM}

The SEM images of the NNM before and after adsorption for U(VI) ions are presented in Fig. (12). As shown in Fig. (12a), the surface of NNM before adsorption was smooth. However, its surface became bumpy and was covered with some material containing uranium, as shown in Fig. (12b). It can also be observed that there were some cleavage and small opening after adsorption. The reason for this was probably that the rehydration of NNM in the aqueous solution resulted in the enhancement of the d-spacing [23].

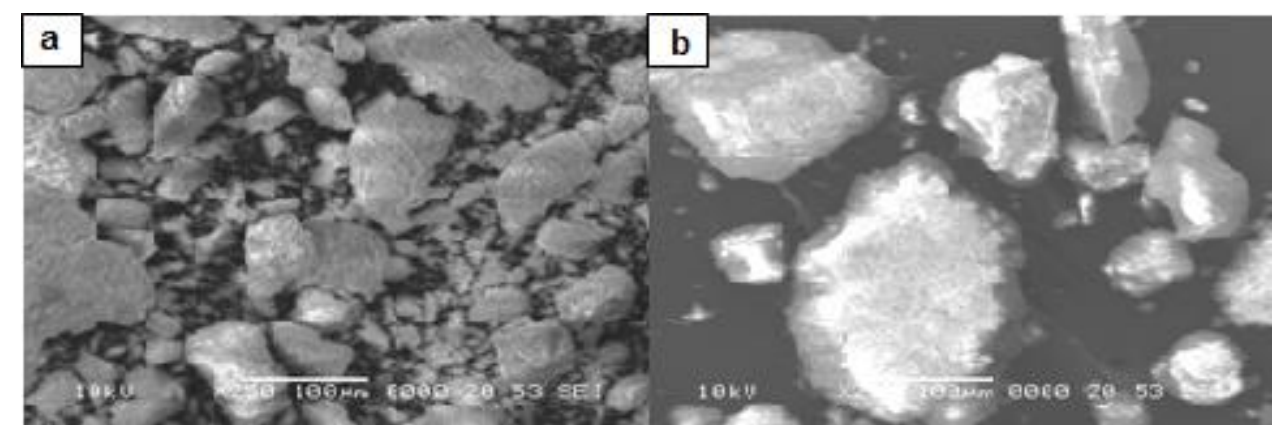

Fig. 12: SEM images for TASF before (a) and after (b) adsorption for $U$ (VI) ions

\section{Case study (Uranium removal from the raffinate solution)}

- Uranium adsorption

As previously stated, the studied NNM adsorbent has a suitable uranium adsorption capacity (about $61 \mathrm{mg} \mathrm{U/g} \mathrm{NNM).} \mathrm{In} \mathrm{the} \mathrm{present} \mathrm{work,} \mathrm{the} \mathrm{study}$ of uranium removal from Nuclear Material Authority, Egypt, liquid raffinate solution was carried out. Batch experiment was performed by contacting $1 \mathrm{~g}$ NNM with $200 \mathrm{ml}$ of raffinate for $30 \mathrm{~min}$. by calculating the loaded uranium content from its analysis in the effluent samples exposed that only about 39 
mg U/g NNM. Comparing this loading capacity with the obtained theoretical capacity of NNM (about $61 \mathrm{mg} \mathrm{U/g} \mathrm{NNM}$ ), designates that under the working conditions about $63 \%$ of the theoretical capacity was realized.

The decrease in the NNM capacity after contacting with the raffinate sample may be due to the competition between uranium and different ions in the studied nuclear waste sample (specially iron).

\section{Conclusion}

About $61 \mathrm{mg} / \mathrm{g}$ of uranium (VI) could be removed by applying the obtained conditions. The preferred conditions for uranium removal from the studied liquid are mainly, solution $\mathrm{pH}$ of about 3, contact time of $30 \mathrm{~min}$, Initial uranium Conc. $100 \mathrm{mg} / \mathrm{l}$ Natural Nile Mud Adsorbent mass (dose) of $2.5 \mathrm{~g} / \mathrm{L}$, temperature of $25^{\circ} \mathrm{C}$ and interfering element of not more than $150 \mathrm{mg} / \mathrm{L}$ as $\mathrm{Fe}^{+3}$. About $92 \%$ of the uranium amount could be loaded on the NNM by applying the latter preferred conditions. By using the studied material for uranium removal from raffinate solution about $63 \%$ of the theoretical capacity was realized, this difference between theoretical and applied capacities is due to the competition between the presient iron and uranium to be adsorbed on the limited adsorption sites.

\section{Acknowledgement}

The author would like to express his sincere thanks to Prof. Dr. Hady Solyman Gado for his thorough revision of the manuscript and for his deeply useful scientific discussions.

\section{References}

1. Nibou, D., Khemaissia, S., Amokrane, S., Barkat, M., Chegrouche, S., \& Mellah, A. (2011). Removal of $\mathrm{UO}_{2}{ }^{2+}$ onto synthetic NaA zeolite. Characterization, equilibrium and kinetic studies. Chemical Engineering Journal, 172(1), 296-305.

2. Ismail, A. F., \& Yim, M. S. (2015). Investigation of activated carbon adsorbent electrode for electrosorption-based uranium extraction from seawater. Nuclear Engineering and Technology, 47(5), 579-587.

3. Bachmaf S., Planer-Friedrich B., \& Merkel, B. J. (2008). Effect of sulfate, carbonate, and phosphate on the uranium (VI) sorption behavior onto bentonite. Radiochimical Acta, 96(6), 359-366.

4. Wang G., Liu J., Wang X., Xie Z., Deng N. (2009). Adsorption of uranium (VI) from aqueous solution onto cross-linked chitosan. Journal of Hazardous Materials, 168(2), 1053-1058. 
5. Brown P., Gill A., Allen S. (2000). Metal removal from wastewater using peat. Water Research, 34(16), 3907-3916.

6. Febrianto, J., Kosasih, A. N., Sunarso, J., Ju, Y. H., Indraswati, N., \& Ismadji, S. (2009). Equilibrium and kinetic studies in adsorption of heavy metals using biosorbent: a summary of recent studies. Journal of Hazardous Materials, 162(2), 616-645.

7. Ding, D. X., Liu, X. T., Hu, N., Li, G. Y., \& Wang, Y. D. (2012). Removal and recovery of uranium from aqueous solution by tea waste. Journal of Radioanalytical and Nuclear Chemistry, 293(3), 735741.

8. Aly, Z., \& Luca, V. (2013). Uranium extraction from aqueous solution using dried and pyrolyzed tea and coffee wastes. Journal of Radio analytical and Nuclear Chemistry, 295(2), 889-900.

9. Bagherifam, S., Lakzian, A., Ahmadi, S. J., Rahimi, M. F., \& Halajnia, A. (2010). Uranium removal from aqueous solutions by wood powder and wheat straw. Journal of radioanalytical and nuclear chemistry, 283(2), 289-296.

10. Kim, J. H., Lee, H. I., Yeon, J. W., Jung, Y., \& Kim, J. M. (2010). Removal of uranium (VI) from aqueous solutions by nanoporous carbon and its chelating polymer composite. Journal of Radioanalytical and Nuclear Chemistry, 286(1), 129-133.

11. Kütahyal1, C., \& Eral, M. (2010). Sorption studies of uranium and thorium on activated carbon prepared from olive stones: kinetic and thermodynamic aspects. Journal of Nuclear Materials, 396(2), 251-256.

12. Hsi, C. K. D., \& Langmuir, D. (1985). Adsorption of uranyl onto ferric oxyhydroxides: application of the surface complexation site-binding model. Geochemical and Cosmochimica Acta, 49(9), 1931-1941.

13. Marczenko Z., (1986): John Wiley and Sons Inc., Harwood, New York, 12(3), 573-590.

14. Breen C., Watson R. (1998). Acid-activated organoclays: preparation, characterisation and catalytic activity of polycation-treated bentonites. Applied Clay Science, 12(6), 479-494.

15. Christidis, G. E., Scott, P. W., \& Dunham, A. C. (1997). Acid activation and bleaching capacity of bentonites from the islands of Milos and Chios, Aegean, Greece. Applied Clay Science, 12(4), 329-347.

16. Chen, Y., Wu, F., Lin, Y., Deng, N., Bazhin, N., \& Glebov, E. (2007). Photodegradation of glyphosate in the ferrioxalate system. Journal of Hazardous Materials, 148(1), 360-365.

17. Arami, M., Limaee, N. Y., Mahmoodi, N. M., \& Tabrizi, N. S. (2005). Removal of dyes from colored textile wastewater by orange peel 
adsorbent: equilibrium and kinetic studies. Journal of Colloid and Interface Science, 288(2), 371-376.

18. Parab, H., Joshi, S., Shenoy, N., Verma, R., Lali, A., \& Sudersanan, M. (2005). Uranium removal from aqueous solution by coir pith: equilibrium and kinetic studies. Bioresource Technology, 96(11), 1241-1248.

19. Chegrouche, S., Mellah, A., \& Telmoune, S. (1997). Removal of lanthanum from aqueous solutions by natural bentonite. Water Research, 31(7), 1733-1737.

20. Bhatnagar, A., \& Jain, A. K. (2005). A comparative adsorption study with different industrial wastes as adsorbents for the removal of cationic dyes from water. Journal of Colloid and Interface Science, 281(1), 49-55.

21. Ho Y.,McKay G. (1999). The sorption of lead (II) ions on peat. Water Research, 33(2), 578-584.

22. Mukhopadhyay B, Walther JV (2001) Acid-base chemistry of albite surfaces in aqueous solutions at standard temperature and pressure. Chemical Geol 17(4), 415-443. 


\section{إزالة اليورانيوم من النفايات السائلة بواسطة طمي النيل الطبيعى \\ منير زكي سعد1 احمد السيد ماضي حسين2 خالا منصور الجندى 1

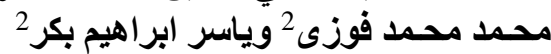 \\ 1 جامعة الزقازيق - كلبة العلوم- قسم الكيمياء

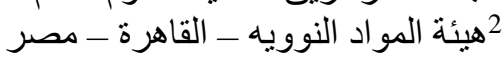

خلاصة

يتعامل هذا البحث على إز الة اليور انيوم من النفايات السائلة باستخدام طمى النيل الطبيعي. وبناءً عليه، فلقد نم تطبيق نهج ذو تكلفة رخيصة وفعالة لإز الة اليور انيوم من النفايات السائلة. فى هذا الصدد نم دراسة الظروف المؤثره على عملية الازالة مثل، درجة الأس الهيدروجينى المحلول، تركيز

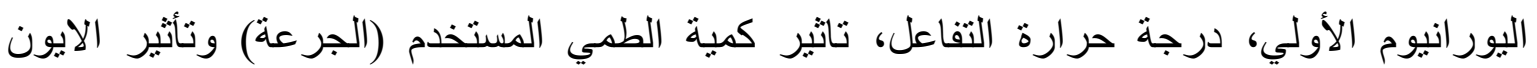

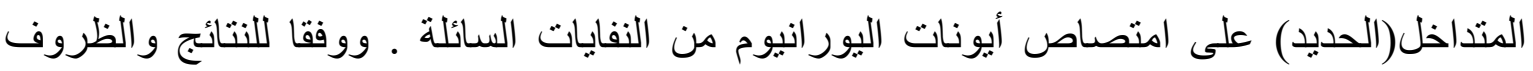
المثلى لأقصى قدر من كفاءة الامتزاز فقد تمت دراسة الاتزان الايزوثيرمى وتمت معات معالجة النتائج المتحصل عليها مع نموذج لانجمير وفرندليش وقد كان نموذج لانجمير هو الأنسب فى وصف النى النتائج مشيراً إلى أن سعة الإدمصاص النظرية هى لآ مجم يور انيوم لكل جر ام من طمى النيل الطبيعى. 